\title{
Eliminating 'Thick' Borders: Analysing the Legal Framework on Non-Tariff Barriers in the Africa Continental Free Trade Area Agreement
}

\author{
Catherine N. Penda ${ }^{*}$
}

\section{Abstract}

African countries have long recognised that regional integration is vital if Africa is to optimise its growth potential and boost its bargaining power in the global marketplace. This explains the proliferation of several Regional Trade Agreements (RTAs) across the continent culminating in the conclusion of the landmark African Continental Free Trade Area (AfCFTA). However, despite the concerted efforts to boost intra-trade among African countries, African borders remain 'thick' because of the continued existence of Non-Tariff Barriers (NTBs) that reverse gains made from initiatives of trade liberalisation. Accordingly, if the landmark Africa Continental Free Trade Area (AfCFTA) is to be successful, it must strive to address and eliminate Africa's NTBs. It is argued in this paper that while the AfCFTA makes some important strides in reducing NTBs in intra-African trade, there are still some significant gaps in the AfCFTA's provisions on NTBs that need to be addressed. Some of these gaps include: the lack of a comprehensive legal framework that adequately addresses all the categories of NTBs and the lack of clear guidelines on how to promote harmonisation among conflicting measures among RTAs. This article singles out and analyses provisions on NTBs under the AfCFTA with the aim of determining whether the AfCFTA addresses the challenges currently facing other RTAs in tackling NTBs. The author will identify shortcomings in the legal framework of the AfCFTA with the aim of making proposals to address them.

Keywords: African Continental Free Trade Area (AfCFTA), Non-Tariff Barriers (NTBs), Regional Trade Agreements (RTAs), Regional Economic Communities (RECs), Common Market for Eastern and Southern Africa (COMESA), Economic Communities

* The author is a post-graduate diploma-in-law student at the Kenya School of Law. 


\section{Table of Contents}

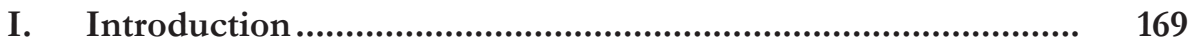

II. The Legal Frameworks on the Elimination of NTBs in RTAs and their Effectiveness............................................................ 173

i. Health and safety measures ................................................................. 173

ii. Restrictive trade policies ...................................................................... 174

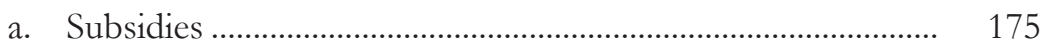

b. Quantitative restrictions ............................................................. 176

iii. Administrative NTBs ...................................................................... 177

a. Rules of origin ...................................................................... 177

b. Custom and administrative entry procedures ........................ 179

iv. Institutions for the elimination of NTBs in the RTAs.......................... 180

III. Legal Framework for the Elimination of NTBs in the AfCFTA: Lessons from RTAs............................................................. 181

i. Government participation in trade and restrictive practices tolerated by governments ............................................................................. 181

ii. Customs and administrative entry procedures........................................ 183

a. Customs procedures ................................................................ 183

b. Rules of origin .................................................................... 184

iii. Technical barriers to trade (TBT)..................................................... 185

iv. Sanitary and phytosanitary measures................................................... 186

v. Specific limitations........................................................................... 187

vi. Charges on imports ........................................................................ 188

vii. Institutions for the Elimination of NTBs in the AfCFTA ................... 189

IV. Recommendations .............................................................. 190

V. Conclusion ............................................................................. 193 


\section{Introduction}

On 21 March 2018, the African continent witnessed the achievement of a milestone in its journey towards economic integration as African leaders representing 44 countries signed the framework agreement establishing the African Continental Free Trade Area (AfCFTA). ${ }^{1}$ The AfCFTA aims to cover an area worth over 'US $\$ 3$ trillion in Gross Domestic Product (GDP) and bring together more than 1.2 billion people from 55 countries'. ${ }^{2}$ As of 1 April 2019, 22 countries had deposited their instruments of ratification with the African Union (AU) paving the way for the entry into force of the Agreement on 30 May 2019 and launching of the operational phase of the AfCFTA on 7 July 2019. ${ }^{3}$ As at 5 March 2021, 36 countries had ratified the AfCFTA that commenced on 1 January 2021. ${ }^{4}$ This initiative has been lauded as a potential game changer for Africa due to its capacity to boost intra-African trade and double this trade if non-tariff barriers are also reduced. ${ }^{5}$

Regional integration is not a novel concept in Africa. ${ }^{6}$ It has been a central part of Africa's development scheme since independence and has been included in key regional development strategies. ${ }^{7}$ To date, the AU recognises eight Regional

1 Shaban A, 'Forty-four countries sign historic African Union free trade agreement' Africa News, 21 March 2018 - https://www.africanews.com/2018/03/21/forty-four-countries-sign-historic-africaunion-free-trade-agreement// - on 6 May 2020.

2 Ernst and Young, African Union launches operational phase of the Africa Continental Free Trade Area,2019, 2.

3 Article 23 of the AfCFTA stipulates that the AfCFTA shall enter into force 30 days after the $22^{\text {nd }}$ instrument of ratification is deposited with the Chairperson of the African Union Commission (AUC). See African Union, Operational phase of the African Continental Free Trade Area launched' Africa Union, 7 July 2019 - https://au.int/en/articles/operational-phase-african-continental-free-tradearea-launched on 15 June 2020.

4 The AfCFTA commencement date was supposed to be on 1 July 2020, but it was postponed to 1 January 2021 due to disruptions caused by the corona virus pandemic that made it difficult to conclude the outstanding negotiations. See Trade Law Centre, Towards the African Continental Free Trade Area: Status of AfCFTA ratification, 6 May 2020 - https://www.tralac.org/resources/byregion/cfta.html> on 5 March 2021. See Ighobor K, AfCFTA Secretariat commissioned in Accra as free trade is set to begin in January 2021', Africa Renewal, 17 August 2020 - https://www.un.org/ africarenewal/magazine/august-2020/arz/afcfta-secretariat-commissioned-accra-free-trade-setbegin-january-2021\#: :text $=$ Trading $\% 20$ under $\% 20$ the $\% 20$ AfCFTA $\% 20$ that,according $\% 20$ to $\% 20$ the $\% 20$ African $\% 20$ Union.\&text $=\% \mathrm{E} 2 \% 80 \%$ C Increase $\% 20$ in $\% 20$ trade $\% 20$ is $\% 20$ the,deepen $\% 20$ regional $\% 20$ integration $\% 20$ in $\% 20$ Africa. on 2 January 2021.

5 African Union and United Nations Economic Commission for Africa, African Continental Free Trade Area - Updated questions and answers' 31 January 2020, 7. See International Monetary Fund, SubSaharan Africa Recovery Amid Elevated Uncertainty, 19 April 2019, 48. See International Monetary Fund, Is the ACFTA a game change? 2018, 46.

6 Seka P', The road to African integration: A historical perspective' 1(8) Journal of Public Administration and Policy Research, 2009, 160.

7 The Lagos Plan of Action (1980). See The Abuja Treaty (1991). See The Constitutive Act of the African Union (July 2000). See and The African Union Agenda 2063.

Vol. 6:1 (2021) p. 169 
Economic Communities (RECs) and four fully functional Free Trade Areas (FTA) or Custom Unions (CU) of the eight RECs. ${ }^{8}$ In addition, regional integration has been promoted through other mediums that are not acknowledged by the AU such as the Tripartite Free Trade Area (TFTA), the Southern African Customs Union (SACU) and the Central African Economic and Monetary Community (CEMAC). ${ }^{9}$

Nonetheless, despite African countries integrating through various RECs, intra-African trade remains on the lower rungs of the ladder with an average score of 13 to 25 percent..$^{10}$ In fact, it is reported that African countries import more than 90 percent of their goods from outside the continent despite the availability of these goods within the continent. ${ }^{11}$ Most notably, this is attributable to the prevalence of NTBs in the form of restrictive trade policies and administrative bottlenecks that make African borders 'thick' and hinder intra-African trade. ${ }^{12}$

NTBs are the unjustified application of Non-Tariff Measures (NTMs), prohibitions, conditions, or specific market requirements that make importation or exportation of products difficult or costly. ${ }^{13}$ They arise from diverse policy measures such as conventional trade policy tools that seek to regulate the quantities or costs of traded goods, such as quotas or price controls, and measures that primarily pursue non-trade objectives such as the protection of

8 Regional Economic Communities recognised by the African Union include: the Arab Maghreb Union (UMA); the Common Market for Eastern and Southern Africa (COMESA); the Community of Sahel-Saharan States (CEN-SAD); the East African Community (EAC); the Economic Community of Central African States (ECCAS); the Economic Community of East African States (ECOWAS); the Intergovernmental Authority on Development (IGAD) and the Southern African Development Community (SADC). COMESA, ECOWAS and SADC, collectively referred to as RTAs, have been recognised to be the AU as either a FTA or CU. See Pan-African Quality Infrastructure, Technical barriers to trade and sanitary and phytosanitary policies of African regional economic communities, 2017, 8.

9 African Union, Economic Commission for Africa and Africa Development Bank, Assessing regional integration in Africa VIII: Bringing the Continental Free Trade Area, 2017, 35.

10 African Union, Economic Commission for Africa and Africa Development Bank, Africa regional integration index report 2019, 2019, 6 and 27; European Union, Press release - EU supports the new African Union Trade Observatory, 9 February 2019, 1. Suiminen H and Luke D, 'The African Continental Free Trade Area: Dawn of a new era' Trade for Development News, 11 June 2019 - https:// trade4devnews.enhancedif.org/en/news/african-continental-free-trade-area-dawn-new-era on 10 June 2020.

11 Trudi H, 'Regional integration in Africa' WTO staff Working Paper, No. ERSD-2011-14, 2011, 10 - https://www.econstor.eu/bitstream/10419/57595/1/669412368.pdf on 10 June 2020.

12 Mold A, 'Non-tariff barriers - Their prevalence and relevance for African countries' African Trade Policy Centre, 2005, 25.

13 Non-Tariff Barriers: Reporting, monitoring and elimination mechanism, 'Non-tariff barriers to trade'https://www.tradebarriers.org/ntb/non_tariff_barriers on 20 June 2020. See Mbori O, 'Combating unjustified sanitary and phytosanitary measures in the African tripartite free trade area (SADCEAC-COMESA): SPS-Plus or SPS-Minus?' 58(4) Hungarian Journal of Legal Studies, 2017, 410.

Vol. 6:1 (2021) p. 170 
health and the environment. ${ }^{14}$ Measures that pursue well-founded non-trade objectives are considered allowable NTMs. ${ }^{15}$ They are an essential element of a country's sovereign right to oversee and regulate its internal affairs. ${ }^{16}$ However, if they are not well designed and regulated, NTMs may be may be used as vehicles of disguised protectionism that restrict and distort international trade presented as legitimate government concerns. ${ }^{17}$

NTBs are considered the main obstacle to international trade. ${ }^{18}$ Their restrictiveness and impact surpass the impact of tariffs by far. For example, the average overall trade restrictiveness of health and safety measures has been estimated to be two to three times higher than the tariff-only restrictiveness. ${ }^{19}$ While tariff reduction is essential for increasing intra-African trade, NTBs must also be reduced in order to unlock the full benefits of tariff reductions. ${ }^{20}$ RTAs in Africa have achieved great success in reducing tariffs but have made little progress in eliminating NTBs. ${ }^{21}$

NTBs work against the main objective of trade liberalisation and eliminate potential gains made from tariff reduction. ${ }^{22}$ Their prevalence in Africa is featured by the Africa Regional Integration Index Report that notes that Africa has the highest average NTBs in the world. ${ }^{23}$ NTBs remain prevalent across the

14 United Nations Conference for Trade and Development (UNCTAD), If you care about least developed countries care about non-tariff measures, 2015, 2. See OECD, Looking beyond tariffs: The role of non-tariff barriers in world trade, 2005, 13.

15 United Nations Conference on Trade and Development, Non-tariff measures to trade: Economic and policy issues, 2013, vii.

16 United Nations Conference on Trade and Development, Non-tariff measures to trade: Economic and policy issues, vii.

17 United Nations Conference on Trade and Development, Non-tariff measures and regional integration in the Southern African Development Community, 2015,1. See United Nations Conference on Trade and Development, Non-tariff measures to trade: Economic and policy issues, vii. See World Bank Group and UNCTAD, The unseen impact of nontariff measures, 2017, 1. Schubert W, 'Fishing for NTBs: The catfish wars as a rent-seeking problem' 32(1) Journal of Macromarketing, 2012, 122-123. See Kim M, 'Disguised protectionism and linkages to the GATT/WTO' 63(3) World Politics Journal, 2012, 427.

18 Osiemo O, 'The last frontier: Sanitary and phytosanitary standards and technical regulations as Nontariff barriers in intra-African trade' 23(1) African Journal of International and Comparative Law, 2015, 176.

19 Kee HL, Nicita A and Olarreaga M, 'Estimating trade restrictiveness indices' 119(534) Economic Journal, 2006, 119, 172-199.

20 Musser R, 'The real problem for intra-African trade' Cipe Blog, 23 October 2015 - https://www. cipe.org/blog/2015/10/23/the-real-problem-for-intra-african-trade/ on 20 July 2020.

21 International Monetary Fund, The African Continental Free Trade Area: Potential economic impact and challenges, 13.

22 Ikhide S and Mushonga M, 'An evaluation of the effectiveness of Trade Protocol on Non-Tariff Barriers to Trade in the SADC free trade area' in Monitoring Regional Integration 2015/2016, TRALAC, 2015/16, 212.

23. African Union, Economic Commission for Africa and Africa Development Bank, Africa Regional Integration Index Report 2019,26. 
continent due to the slow implementation of existing commitments to eliminate NTBs and lack of harmony in border measures and technical and sanitary and phytosanitary measures. ${ }^{24}$ This is a result of overlapping membership in RTAs that has led to varying border regulations and standard related requirements. ${ }^{25}$

Against this background, non-tariff trade costs are the most important barriers to trade due to their ability to boost intra-trade more than tariff elimination. ${ }^{26}$ Therefore, unless the AfCFTA is shaped as a comprehensive legal framework that focuses on addressing NTBs prevalent in the continent, the trade benefits of the AfCFTA will remain hard to achieve. In particular, the regional and national institutions created to monitor and eliminate NTBs must be supported with an appropriate legal framework that promotes harmonisation and prohibits the enactment of restrictive national policies.

This study makes two key claims. Firstly, while the AfCFTA adopts the same definition of NTBs as RTAs, the AfCFTA goes beyond these definitional similarities by also delineating NTBs into clear identifiable categories, resolving some contradictions in the various RTAs and generally including more robust measures to reduce NTBS in intra-African trade. Secondly, despite these improvements, there are still some important gaps in the AfCFTA's provisions on NTBs that will need to be re-considered and addressed moving forward. These, for example, include: provisions on the rules of origin, subsidies, and other categories of NTBs that are still ambiguous as well as provisions on legal standing in the NTBs dispute resolution mechanisms.

This paper focuses on analysing and critically evaluating the legal framework addressing NTBs in the AfCFTA. The first section of this paper gave a brief introduction to regional integration and NTBs in Africa. This part also appreciated the importance of why governments put in place NTBs and unpacks the reasons why it is still important to eliminate them. Part II and Part III follow by analysing the legal infrastructure addressing the prevalent NTBs in Africa under the RTAs and the AfCFTA respectively. This part highlights existing gaps in the RTAs and AfCFTA legal framework on NTBs. In Part III, a comparative

24 Viljoen W, 'The African Continental Free Trade Area (AfCFTA) and non-tariff barriers' TRALAC - https://www.tralac.org/discussions/article/12866-the-african-continental-free-trade-area-afcftaand-non-tariff-barriers-ntbs.html on 15 July 2020.

25 - https://www.tralac.org/discussions/article/12866-the-african-continental-free-trade-area-afcftaand-non-tariff-barriers-ntbs.html on 15 July 2020.

26 Saygili M, Peters R and Knebel C, 'African Continental Free Trade Area: Challenges and opportunities of tariff reductions' United Nations Conference on Trade And Development (UNCTAD), Research Paper No. 15 UNCTAD/SER.RP/2017/15, 2018, 11 - https://www.wcoesarocb.org/wp-content/ uploads/2018/08/UNCTAD-AfCFTA-Challenges-and-Oppportunities-of-Tariff-Reductions.pdf on 20 June 2020.

Vol. 6:1 (2021) p. 172 
analysis between the NTBs regulatory framework in the AfCFTA and RTAs is also undertaken. In undertaking this analysis, the study will not only analyse the legal provisions on the general categories of NTBs but also the institutional structures, reporting and monitoring tools created to address NTBs. Finally, this paper will make recommendations in Part IV.

\section{The Legal Frameworks on the Elimination of NTBs in RTAs and their Effectiveness}

The use of NTBs is a growing concern in Africa and a major obstacle to regional integration due to the increased business costs and restricted market access. ${ }^{27}$ This is so despite the commitments to eliminate NTBs in African RTAs that call upon member states to remove all the existing NTBs and refrain from imposing any further NTBS. ${ }^{28}$ NTBs in Africa exist in different categories such as: health and safety measures in the form of restrictive technical and sanitary/ phytosanitary measures; restrictive trade policies such as quotas, subsidies, import licences and quantitative restrictions; and administrative NTBs such as complex or dissimilar rules of origin; and restrictive and duplicated and cumbersome customs and administrative entry procedures. ${ }^{29}$

\section{i. Health and safety measures}

Sanitary and Phytosanitary (SPS) measures are standards applied by governments to secure human, animal, or plant life from dangers arising from the entry or spread of pests and diseases and disease-carrying or disease-causing organisms. ${ }^{30}$ They include relevant legislative frameworks and administrative or technical requirements such as final product testing, inspection, certification, packaging, and labelling requirements that governments implement to protect

27 Mutai K, 'Regional trade integration strategies under SADC and the EAC' 1(1) SADC Law Journal, $2011,87$.

28 Article 6, SADC Trade Protocol. See Article 49, Treaty Establishing the Common Market for Eastern and Southern Africa (COMESA). See Article 75(5) Treaty Establishing the East African Economic Community (EAC). See Article 3(d)(i), ECOWAS Revised Treaty.

29 Trudi H, 'Regional integration in Africa', WTO Staff Working Paper, No. ERSD-2011-14, 2011, 10 - https://www.econstor.eu/bitstream/10419/57595/1/669412368.pdf on 10 June 2020, 16. See Ikhide S and Mushonga M, 'An evaluation of the effectiveness of Trade Protocol on Non-Tariff Barriers to Trade in the SADC free trade area' in Monitoring Regional Integration 2015/2016, TRALAC, 2015/16, 211.

30 Du Plessis A, 'The sanitary and phytosanitary (SPS) policies of the African Regional Economic Communities (RECs), and the way forward for the Continental Free Trade Area', Trade Law Centre, 2017, 3 . 
human, plant and animal health and life from pests, diseases and unlawful additives and contaminants in food. ${ }^{31}$ Though necessary to ensure safety, the costs of meeting the set technical and phytosanitary standards may be exorbitant for producers. ${ }^{32}$

COMESA, EAC, ECOWAS and SADC instruments all require members to base their SPS measures on international standards. ${ }^{33}$ They have developed regional SPS policy frameworks, which 'mirror' the World Trade Organisation (WTO) SPS Agreement. ${ }^{34}$ However, these policies repeat, restate in part, and rephrase selected parts of the texts of the WTO SPS Agreement and have been criticised for leading the omission or amendment of important rules and safeguards contained in WTO Agreements. ${ }^{35}$ For example, the COMESA Regulations are considered contradictory to obligations under the WTO SPS Agreement due to partially using the text of the SPS Agreement out of its context the and use of a different set of words, which modify the SPS Agreement. ${ }^{36}$ In addition, health and safety measures implemented by African RTAs have led to the duplication, overlapping and contradiction of SPS policies. ${ }^{37}$

\section{ii. Restrictive trade policies}

Restrictive trade policies are policies that seek to protect domestic markets and limit international trade and competition. ${ }^{38}$ They exist in the form of

31 Mahmoud B, 'International food safety: An overview of the Sanitary and the Phytosanitary Agreement' on 3 November 2017 - https://www.agrilinks.org/post/international-food-safetyoverview-sanitary-and-phytosanitary-sps-agreement on 17 July 2020. See Du Plessis A, 'The Sanitary and Phytosanitary (SPS) policies of the African Regional Economic Communities (RECs), and the way forward for the Continental Free Trade Area', 3.

32 United Nations Economic Commission for Africa, The Continental Free Trade Area (CFTA) in Africa - A buman rights perspective, 2017, 108.

33 Article 132 (d), Treaty Establishing the Common Market for Eastern and Central Africa (COMESA), 30 September 1982. Article 16 (1), Protocol Establishing the Southern African Development Community (SADC), Article 108 (a), Treaty for the Establishment of the East African Community (EAC),2000.

34 Magalhaes J, 'Regional sanitary and phytosanitary frameworks and strategies in Africa' Standards and Trade Development Facility, 2010, para 2, XI: Mbori O, 'Combating unjustified sanitary and phytosanitary measures in the African tripartite free trade area (SADC-EAC-COMESA): SPS-Plus or SPS-Minus?', 426.

35 Du Plessis A, 'The sanitary and phytosanitary (SPS) policies of the African Regional Economic Communities (RECs), and the way forward for the Continental Free Trade Area', 9.

36 Magalhaes J, 'Regional sanitary and phytosanitary frameworks and strategies in Africa' para 52, 10.

37 Magalhaes J, 'Regional sanitary and phytosanitary frameworks and strategies in Africa' para 111, 23: Osiemo O, 'The last frontier: Sanitary and phytosanitary standards and technical regulations as nontariff barriers in intra-African trade' 187.

38 Morrissey O, 'Trade policy and performance in Sub Saharan Africa' University of Nottingham School of Economics, 2004, 10.

Vol. 6:1 (2021) p. 174 
subsidies that aid and have a financial benefit to the industry concerned or in the form of quantitative restrictions that limit the quantity of a product that may be imported or exported. ${ }^{39}$

\section{a. Subsidies}

Subsidies are used as a tool for realising government policies in the form of grants, tax exemptions, low-interest financing and investments and export credits..$^{40}$ They distort the competitive relationships that exist in a free trading system as they give domestic industries protection. ${ }^{41}$ To boost agricultural production, African governments have resorted to the use of subsidies in agricultural inputs. ${ }^{42}$ These are countries like Malawi and Ghana that have adopted fertilizer and seed subsidy programmes to increase their food production. ${ }^{43}$ Though subsidies may be necessary to promote noble objectives such as food security, it is important to note that they move away from the ongoing liberalisation processes in Africa and may be disguised protectionist tools that seek to promote self-sufficiency and distort competition. ${ }^{44}$

The SADC, COMESA and EAC trade agreements prohibit member states from using subsidies that distort or threaten competition..$^{45}$ The SADC regulations on subsidies expressly prohibit members from granting subsidies that distort competition in the SADC region. ${ }^{46} \mathrm{~A}$ similar provision is found under Article 52 of the COMESA Treaty. ${ }^{47}$ In addition, the COMESA Treaty goes a step further than the SADC Protocol by also prohibiting subsidies that affect trade between

39 Bossche P, The law and policy of the World Trade Organisation: Text, cases and materials, Cambridge University Press, UK, 2010, 441.

40 World Trade Organisation, Subsidies and the WTO, 2006, 189.

41 World Trade Organisation, Subsidies and the WTO, 2006, 189.

42 Food and Agriculture Organisation of the United Nations, Agricultural policy incentives in sub-Sabaran Africa in the last decade (2005-2016): Monitoring and analysing Food and agricultural policies (MAFAP) synthesis study, 2018, 41.

43 Carr S, 'Addressing Africa's real agricultural issues' Thrive Blog, 8 July 2015 - https://wle.cgiar.org/ thrive/big-questions/does-farm-size-really-matter-africa/african-agriculture-does-farm-size-really on 5 July 2020.

44 Food and Agriculture Organisation of the United Nations, Agricultural policy incentives in sub-Saharan Africa in the last decade (2005-2016): Monitoring and Analysing Food and agricultural policies (MAFAP) synthesis study, 51 .

45 Article 52, COMESA Treaty, Article 19, SADC ProtocolSee Annex V, EAC Customs Union Subsidies and Countervailing Measures Regulations.

46 Article 19 (1), SADC Protocol.

47 Any subsidy granted by a Member State or through state resources in any form whatsoever which distorts or threatens to distort competition by favouring certain undertakings or the production of certain goods shall, in so far as it affects trade between the Member States, be incompatible with the common market. See Article 52(1), COMESA Treaty. 
member states and a third country. ${ }^{48}$ In the EAC, Article 17 (1) of the EAC Protocol does not expressly prohibit the use of subsidies. Nonetheless, members are required to notify other EAC partners of any subsidies implemented. ${ }^{49}$ The EAC has also promulgated the EAC Subsidies and Countervailing Measures Regulations that set out the legal parameters regulating the use of subsidies in the EAC. ${ }^{50}$ A reading of the Protocol Establishing ECOWAS does not show any legal provisions on the use of subsidies.

In addition, both COMESA, and SADC contain provisions on the protection and promotion of infant industries. ${ }^{51}$ However, neither the COMESA Treaty nor the SADC Protocol define infant industries. This raises questions on what is considered an infant industry and makes the provision susceptible to abuse by member states who may seek to protect less innovative industries that are not able to survive without protection. ${ }^{52}$

\section{b. Quantitative restrictions}

On the other hand, a quantitative restriction is a measure which limits the quantity of a product that may be imported or exported. ${ }^{53}$ Quantitative restrictions are used as an alternative to tariffs for purposes of restricting trade. ${ }^{54}$ They exist in different forms such quotas, non-automatic licensing, bans, prohibitions and other restrictions with a similar effect. ${ }^{55}$ Articles 7 (1) and 8 (1) of the SADC Protocol provide for the phasing out of quantitative restrictions on imports and exports originating in or destined for other SADC countries. ${ }^{56}$ Article 41(1) of the ECOWAS Revised Treaty requires member states to gradually remove, eliminate and refrain from the use of quotas or quantitative like restrictions or prohibitions. ${ }^{57}$ Similar provisions exist in the COMESA and EAC instruments. ${ }^{58}$ However, despite the general prohibition on the use of quantitative restrictions

\footnotetext{
48 Article 52 (3), COMESA Treaty.

49 Article 17 (1), EAC Protocol.

50 The EAC Customs Union Subsidies and Countervailing Measures Regulations give the definition of subsidies and categories of subsidies as actionable, prohibited, and non-actionable subsidies.

51 Article 49 (2), COMESA Treaty: Article 2, SADC Protocol.

52 Mukucha Ephraim, 'The regulation and impact of non-tariff barriers to trade in SADC free trade area’ Unpublished LLM Thesis, University of Pretoria, Pretoria, 2011, 42.

53 Bossche P, The Law and Policy of the World Trade Organisation: Text, Cases and Materials, 441.

54 Mutai K, 'Regional integration strategies under SADC and the EAC: A comparative analysis' 1(1) SADC Law Journal, 2011, 89.

55 Bossche P, The Law and Policy of the World Trade Organisation: Text, Cases and Materials, 441.

56 Article 7 (1) and 8 (1), SADC Protocol.

57 Article 41(1), Revised Treaty Establishing the Economic Community of West African States, 1975.

58 Article 45, COMESA Treaty; Article 75 (5) EAC Protocol
}

Vol. 6:1 (2021) p. 176 
member states have still reported complaints on the continued use of quantitative restrictions as a result of lack of political will to eliminate them. ${ }^{59}$

\section{iii. Administrative NTBs}

Administrative trade barriers are bureaucratic procedures (red tape) that a trading firm has to get through when shipping the product from one country to the other. ${ }^{60}$ They exist as a result of legal and regulatory requirements that give rise to cumbersome administrative procedures. ${ }^{61}$

\section{a. Rules of origin}

Rules of origin are the criteria used to define the origin of a product to determine whether the product is eligible for preferential treatment in the case of preferential rules of origin or for origin marking and to enforce trade measures such as anti-dumping and countervailing duties in the case of non-preferential rules of origin. ${ }^{62}$ Rules of origin are an important and necessary tool in trade agreements. However, they have extensive repercussions on the depth and pattern of regional integration because they influence the choice of raw materials used in the production of goods eligible for preferential treatment. ${ }^{63}$ Against this background, complex rules of origin can restrict trade and misdirect investment as they can be used to control market access or pursue economic development objectives. ${ }^{64}$

In COMESA and the EAC, goods are considered as originating goods based on the wholly obtained or produced criteria. ${ }^{65}$ In COMESA, goods are considered as originating if the goods are wholly produced in a member state

59 Non-Tariff Barriers: Reporting, Monitoring and Elimination Mechanism, 'Resolved complaints: NTB-000-474, NTB-000-469, NTB-000-146' - https://www.tradebarriers.org/resolved_ complaints/page:2/search:ban on 1 August 2020.

60 Koren $\mathrm{M}$ and Hornok C, 'Administrative barriers and the lumpiness of trade' EFIGE Working Paper Number 36, 2011, 2 - https://www.bruegel.org/wp-content/uploads/2015/09/efige_ wp36_2410111.pdf on 27 August 2020.

${ }_{61}$ Bjelic' P, 'Administrative barriers to trade as predominant non-tariff barriers in the Western Balkans trade' International Conference on International Trade and Investment, Mauritius, August 2013, 3.

62 Estevadeon A, Harris J and Suomen K, 'Multilateralising preferential rules of origin around the world' Inter-American Development Bank, IDB Working Paper Series IDB-WP-137, 2009, 3 https://publications.iadb.org/publications/english/document/Multilateralising-Preferential-Rulesof-Origin-around-the-World.pdf on 1 August 2020.

63 United Nations Conference on Trade and Development, Economic development in Africa, 2019, 7.

64 Gretton P and Gali J, ' The restrictiveness of rules of origin in preferential trade agreements' $34^{\text {th }}$ Conference of Economists at University of Melbourne, Canberra, 26-28 September 2005, 1.

65 Rule 4, EAC Rules of Origin Rules, 2015: Rule 2, COMESA Protocol on the Rules of Origin, 1994.

Vol. 6:1 (2021) p. 177 
or if the goods are produced in a member state: the c.i.f. value of any foreign materials should not exceed 60 percent of the total cost of all materials used in their production; or the goods should attain a value added of at least 35 percent of the ex-factory cost of the goods; or goods should be classifiable under a tariff heading different from the tariff heading of the non-originating materials used in production. ${ }^{66}$ COMESA also grants originating status to goods designated as goods of economic importance where the goods do not contain less than 25 percent value added. ${ }^{67}$ The EAC rules of origin are similar to COMESA's rules of origin as they both require goods obtained in a member state to attain value added of at least 35 percent of the ex-factory and limit the c.i.f. value of any foreign materials to 60 percent of the total cost of all materials used in their production. ${ }^{68}$ However, the EAC does not grant originating status to goods of economic importance.

Unlike COMESA and EAC that set out several independent criteria for grant originating status to goods, ECOWAS grants goods originating status based on a narrower criterion. ECOWAS grants originating status to goods that are either wholly produced in member states or goods that have received a valueadded of at least 30 percent of the ex-factory price of the finished goods. ${ }^{69}$ ECOWAS does not grant originating status based on change tariff classification and percentage limits on the c.i.f. value of any foreign materials of the total cost of all materials used in their production.

The SADC rules of origin are considered complex and restrictive. ${ }^{70}$ This is due to the 'made to measure sector specific rules' and the multiple transformation rules on required production processes instead of the use of tariff headings. ${ }^{71}$ A good example is the double transformation rule that ensures producers using imported inputs cannot compete on a regional basis in SADC. ${ }^{72}$ Mauritius, a member of SADC, has lodged complaints on SADC's double transformation

\footnotetext{
66 Rule 2.2.3, COMESA Protocol on the Rules of Origin.

67 Rule 2.2.3, COMESA Protocol on the Rules of Origin.

68 Rule 4 (1), EAC Rules of Origin Rules.

69 Article 4, Protocol A/P1/1/03 Relating to the Definition of The Concept of Products Originating from Member States of ECOWAS, 2003.

70 Brenton P, Flatters F and Kalenga P, 'Rules of origin and SADC: The case for change in the midterm review of the Trade Protocol', Africa Region Working Paper Series No. 83, 2005, ii - http:// qed.econ.queensu.ca/pub/faculty/flatters/writings/ff_pb_pk_sadc_roo_wbarwp83.pdf on 7 August 2020.

71 Brenton $\mathrm{P}$ et al, 'Rules of origin and SADC: The case for change in the mid-term review of the Trade Protocol', 17.

72 Brenton $\mathrm{P}$ et al, 'Rules of origin and SADC: The case for change in the mid-term review of the Trade Protocol', 30 .
}

Vol. 6:1 (2021) p. 178 
rule on the grounds that it is too rigid as it hampers manufacturing of clothing due to the challenges in obtaining the SADC certificate of origin. This is because of the non-recognition of cutting and printing as a valuable part of production of imported fabrics despite the fact that this accounts for a big part of the value of this product. ${ }^{73}$ This complaint is yet to be resolved since 2015 when it was lodged before the COMESA, EAC and SADC's NTBs reporting, monitoring and elimination mechanisms. ${ }^{74}$

RTA in Africa have different preferential rules of origin and lack coordination on rules of origin among members of the same and overlapping RTAs. This complicates the administration and adds to costs of compliance, both for traders as well as governments. ${ }^{75}$

\section{b. Custom and administrative entry procedures}

Customs and administrative entry procedures play a critical role in tax collection and administration and in ensuring adherence to national and international laws that seek to safeguard consumers of foreign-produced goods. ${ }^{76}$ These procedures include: customs valuation; customs classification; consular formalities and documentation; samples; import licensing; pre-shipment inspection and other formalities related to pre- shipment inspection. ${ }^{77}$

However, duplication of clearance procedures and lengthy and complex procedures may become an encumbrance to trade by increasing transaction costs that make it harder for countries to fully exploit the benefits of international trade. ${ }^{78}$ For example, in the EAC, the Tanzania Revenue Authority requires traders to attach an Atomic Energy Certificate before assessment of confectionery products. ${ }^{79}$ This requirement increases transaction costs by 0.4 percent of the value of transaction and increases the clearance period by three to four days as traders must send a sample of their goods to the Tanzania Atomic Energy

73 Non-Tariff Barriers: Reporting, Monitoring and Elimination Mechanism, 'Active complaints: NTB000-676' - https://www.tradebarriers.org/active_complaints/search:rules $\% 20$ of $\% 20$ origin on 25 July 2020.

74 - Non-Tariff Barriers: Reporting, Monitoring and Elimination Mechanism, 'Active complaints: NTB-000-676 https://www.tradebarriers.org/active_complaints/search:rules\%20of $\% 20$ origin on 25 July 2020

75 Keane J et al, 'Impediments to intra-regional trade in Sub-Saharan Africa' Overseas Development Institute, 31.

76 OECD, Policy framework for investment user's toolkit, 2012, 3.

77 Appendix 1 Annex 5 NTBs, Annexes to the AfCFTA.

78 OECD, Policy framework for investment user's toolkit, 2012, 3.

79 Non-Tariff Barriers: Reporting, Monitoring and Elimination Mechanism, 'Active complaints: NTB000-925' 3 June 2019 - https://www.tradebarriers.org/active_complaints/page:2 on 1 August 2020. 
Commission in Arusha. ${ }^{80}$ In addition, the duplication of procedures to obtain standardisation marks causes delays in shipment and increases the costs of transportation. For example, Kenyan traders to Uganda must go through double quality examination procedures due to Uganda's lack of recognition of Kenya's online KEBs standardisation mark. ${ }^{81}$

The cumbersome administrative procedures are a result of the absence of synergy between customs officials and the lack of computerised customs management systems that eliminate prolonged and inefficient manual operations carried out by traders and officials at borders. ${ }^{82}$ This is despite the existence of commitments towards the simplification, harmonisation and standardisation of customs regulations, documents and procedures and the computerisation of custom procedures in African RTAs. ${ }^{83}$

\section{iv. Institutions for the elimination of NTBs in the RTAs}

In recent years, some continental initiatives have been launched to address the prevalence of NTBs across the continent. Most prominent is the use of online mechanisms that have been adopted by RTAs as a tool for monitoring, reporting, and eliminating NTBs. These include the TFTA online reporting, monitoring, and eliminating mechanism for COMESA, EAC and SADC and the Borderless Alliance online reporting and monitoring mechanism for ECOWAS and the West African Economic and Monetary Union. These online mechanisms allow continuous reporting, collection and resolving of NTBs encountered by traders. ${ }^{84}$ These mechanisms have been applauded for their role in reducing the bureaucracy involved in communication between various role players in the private and public sectors to resolve NTBs. ${ }^{85}$ However, these are administrative measures that do not lead to a legally binding solutions. ${ }^{86}$ They focus on mutually

80 Non-Tariff Barriers: Reporting, Monitoring and Elimination Mechanism, 'Active complaints: NTB000-925' 3 June 2019 - https://www.tradebarriers.org/active_complaints/page:2 on 1 August 2020.

81 Non-Tariff Barriers: Reporting, Monitoring and Elimination Mechanism, 'Active complaints: NTB000-922' 30 May 2019 - https://www.tradebarriers.org/active_complaints/page:2 on 1 August 2020.

82 Barka H, 'Border posts, checkpoints and intra-African trade: Challenges and solutions' Africa Development Bank, 2012, 6 - 8.

83 Article 12, Article 5 (3) and Article 4 Annexure II, SADC Protocol. See Article 9 SADC Protocol. See Article 63 and 121 COMESA treaty.

84 Borderless Alliance, the borderless e-platform for reporting and monitoring non-tariff barriers in west Africa, 2011, 1.

85 Borderless Alliance, the borderless e-platform for reporting and monitoring non-tariff barriers in west Africa, 2011, 1.

86 Chidede T, 'The AfCFTA legal framework for the elimination of NTBs' Trade Law Centre, 2019, 6.

Vol. 6:1 (2021) p. 180 
agreeable solutions to reported conflicts. ${ }^{87}$ Accordingly, they have been criticised for the lack of judicial remedies that are binding and that respond to NTBs that keep recurring as a result of defective national legislation. ${ }^{88}$

\section{Legal Framework for the Elimination of NTBs in the AfCFTA: Les- sons from RTAs}

One of the primary objectives of the AfCFTA is the eradication of NTBs to lower the cost of doing business in Africa. ${ }^{89}$ Correspondingly, Annex 5 of the AfCFTA on Non-Tariff Barriers sets out the mechanisms for the elimination of NTBs and the categories of NTBs. The AfCFTA defines NTBs as barriers that impede trade through mechanisms other than the imposition of tariffs. ${ }^{90}$ This official definition is broad and a detailed classification of NTBs has further been laid down to clearly identify and categorise NTBs. ${ }^{91}$ The AfCFTA categorises NTBs into five different groups namely: government participation in trade and restrictive practices tolerated by governments; customs and administrative entry procedures; technical barriers to trade; sanitary and phytosanitary measures; specific limitations; and charges. ${ }^{92}$

\section{i. Government participation in trade and restrictive practices tolerated by governments}

Government participation in trade exists in the form of government aid such as subsidies and tax benefits. ${ }^{93}$ Unlike the SADC Protocol on Trade and the EAC Customs Union Subsidies and Countervailing Measures Regulations that define subsidies, the AfCFTA has no definition of a subsidy. ${ }^{94}$ This leaves the AfCFTA provisions on subsidies ambiguous as it is hard to identify measures that qualify as subsidies prohibited under Appendix 1 Annex 5 NTBS, Annexes to the AfCFTA.

\footnotetext{
87 Chidede T, 'The AfCFTA legal framework for the elimination of NTBs'6.

88 Viljoen W, 'The proposed Tripartite Non-tariff Barrier Elimination Mechanism: An Evaluation of Legal Texts and Practice', TRALAC Annual Conference Organised by TRALAC at Radisson Hotel, Lusaka, 16-17 April 2015, 14-15.

89 Article 4, Agreement establishing the AfCFTA: Article 2, AfCFTA Protocol on Goods.

90 Article 1, AfCFTA Protocol of Trade in Goods

91 United Nations Conference on Trade and Development, 'Classification of NTMs' - https://unctad. org/en/Pages/DITC/Trade-Analysis/Non-Tariff-Measures/NTMs-Classification.aspx on 1 August 2020.

92 Article 3(1) Annex 5 NTBS, Annexes to the AfCFTA.

93 Appendix 1 Annex 5 NTBS, Annexes to the AfCFTA.

94 Regulation 7, EAC Customs Union Subsidies and Countervailing Measures Regulations; Article 1, SADC Protocol.
} 
A reading of Article 17 of the Protocol on the Trade in Services shows that subsidies are not entirely prohibited in the AfCFTA trade in services as member states can use subsidies in relation to their development programs. ${ }^{95}$ Under Article 17(2) of the Protocol on the Trade in Services, state parties commit to deciding on mechanisms for information exchange and review of all subsidies related to trade in the services that member states adopt. ${ }^{96}$ This is a commendable resolution as it will ensure that national subsidy programmes remain transparent. In addition, Article 17(3) of the Protocol on the Trade in Services provides that any state party adversely affected by a subsidy of another state party may request consultations with that state party on such matters. ${ }^{97}$ While this is a positive step towards eliminating subsidies that distort trade, aggrieved parties lack a legally binding method of resolving disputed subsidies as the AfCFTA provides for sympathetic consideration in resolving subsidy disputes. ${ }^{98}$

On the other hand, the AfCFTA does not contain any legal provisions on the use of subsidies in trade in goods and it seems that subsidies related to trade in goods are entirely disallowed in the AfCFTA. The AfCFTA has a blanket prohibition on the use of subsidies in the trade in goods and fails to differentiate between subsidies that distort trade and subsidies that are used to achieve a common interest, such as regional aid, environmental protection, and public service, as subsidies on environmental protection are not NTBs. ${ }^{99}$

In addition, like Article 49 (2) of the COMESA Treaty and Article 2 of the SADC Protocol, Article 24 of the Agreement Establishing the AfCFTA allows state parties to protect infant industries that have strategic importance at the national level so long as they have taken reasonable steps to overcome the difficulties related to such infant industries. ${ }^{100}$ Such measures shall be applied on a non-discriminatory basis and for a specified period of time. ${ }^{101}$ The AfCFTA does not define infant industries nor does it include set time limits on the maximum period of time an industry may be protected as an infant industry. Therefore, the legislative gaps that exist in COMESA and SADC regulations on protection of infant industries continue to exist under the AfCFTA that fails to establish clear guidelines on the protection of infant industries.

\footnotetext{
95 Article 17(1), AfCFTA Protocol in the Trade in Services.

96 Article 17(2), AfCFTA Protocol in the Trade in Services.

97 Article 17(3), AfCFTA Protocol in the Trade in Services.

98 Article 17, AfCFTA Protocol in the Trade in Services.

99 Hoekman B and Nelson D, 'Rethinking international subsidy rules' Global Economic Dynamics, Working Paper Version 28/02/2020, 2020, 20 - 21 - http:/ / aei.pitt.edu/102557/2/MT_Rethinking_ Subsidy_Rules_2020_EN.pdf on 30 July 2020.

100 Article 24(1), Agreement establishing the AfCFTA.

101 Article 24(1), Agreement establishing the AfCFTA.
}

Vol. 6:1 (2021) p. 182 


\section{ii. Customs and administrative entry procedures}

Customs and administrative entry procedures that are considered NTBs include: customs valuation; customs classification; consular formalities and documentation; samples; rules of origin; customs formalities; import licensing; and pre-shipment inspection and other formalities related to pre- shipment inspection. ${ }^{102}$

\section{a. Customs procedures}

Annex 3 of the AfCFTA on Customs Co-operation and Mutual Administrative Assistance seeks to facilitate the simplification and harmonisation of customs procedures to ensure the smooth flow of trade and the integrity of the international supply chain. ${ }^{103}$ State parties are encouraged to ensure that their respective customs authorities use internationally accepted standards, especially those adopted by the World Customs Organisation (WCO), and develop or adopt computerised customs clearance systems. ${ }^{104}$ This is in line with the World Bank policy toolkit on custom clearance processes that recommends the use of simplified and streamlined custom procedures that conform to internationally accepted standards and an appreciation of computerised solutions in custom procedures. ${ }^{105}$ This is commendable as it will provide consistency, predictability and transparency in customs operations. However, the language used in the AfCFTA is not mandatory as states are simply 'encouraged' to use internationally accepted standards. This may lead to inconsistencies in customs procedures as member states may opt out of the internationally accepted standards and adopt their own procedures

On the harmonisation of customs and administrative procedures, both the RTAs and the AfCFTA contain provisions that seek to promote the harmonisation of customs procedures. However, like RTAs, the AfCFTA does not have a detailed plan of action on how to eliminate cumbersome customs and administrative procedures. The AfCFTA does not have a set timeline by which state parties should have harmonised their customs procedures and adopted computerised customs clearance systems. In the absence of a clear plan of action

\footnotetext{
102 Appendix 1 Annex 5 NTBS, Annexes to the AfCFTA.

103 Article 2(1) Annex 3 Customs Co-operation and Mutual Administrative Assistance, Annexes to the AfCFTA.

104 Article 6 Annex 3 Customs Co-operation and Mutual Administrative Assistance, Annexes to the AfCFTA.

105 International Finance Corporation World Bank Group, Reforming the Regulatory Procedures for Import and Export: Guide for Practitioners, 2006, 62.
} 
on how to harmonise customs and administrative procedures, governments will continue to use duplicate, complex and lengthy customs procedures.

\section{b. Rules of origin}

The rules of origin that apply in the AfCFTA are set out in Annex 2 of the Annexes to the AfCFTA. Before delving deeper into this issue, it is important to note that the AfCFTA regulations on rules of origin are yet to be finalised at the time of writing. ${ }^{106}$ Therefore, the regulations might significantly differ from the current position upon further discussion and conclusion of the rules of origin.

In the AfCFTA, a product is considered as originating from a state party if it has been wholly obtained or has undergone substantial transformation. ${ }^{107}$ It is laudable that the AfCFTA does not adopt the complex and restrictive made-tomeasure sector specific rules and the multiple transformation rules adopted by SADC. The wholly obtained criteria include among other products made aboard factory ships, products extracted from marine soil or subsoil outside the territorial waters of AfCFTA member states and electric energy produced therein. ${ }^{108}$ Products which are not wholly obtained are considered to be sufficiently worked or processed when they have: value added; non-originating material content; change in tariff heading; or specific processes. ${ }^{109}$

In addition, it is commendable that the AfCFTA, like COMESA and the EAC, adopts a broad range of different criteria that can be used to determine whether goods are originating from. Accordingly, a broader range of goods is likely to be considered as originating based on the different criteria laid down. However, unlike COMESA, the AfCFTA does not have a lower percent valueadded rule for products regarded as economically important. Nonetheless, it is commendable that the AfCFTA has the lowest value-added requirements for goods to qualify as originating. COMESA and EAC require the value-added to account for at least 35 percent of the ex-factory cost of the product, and ECOWAS requires the value-added to account for at least 30 percent of the ex-factory cost of the product. On the other hand, the AfCFTA only requires

\footnotetext{
106 Appendix IV to Annex 2 on Rules of Origin on the specific requirements for goods to qualify as originating goods is yet to be inserted. See Article 6(2) and Appendix 4 Annex 2 Rules of Origin, Annexes to the AfCFTA. See Viljoen W, 'Rules of origin, tariffs and the AfCFTA' Trade Law Centre Blog, 19 May 2019 - https://www.tralac.org/blog/article/14063-rules-of-origin-tariffs-and-theafcfta.html - on 24 December 2020.

107 Article 4, Annex 2 Rules of Origin, Annexes to the AfCFTA.

108 Article 5(1) Annex 2 Rules of Origin, Annexes to the AfCFTA.

109 Article 6(1) Annex 2 Rules of Origin, Annexes to the AfCFTA.
}

Vol. 6:1 (2021) p. 184 
value addition that accounts for at least 15 percent of the ex-factory costs. ${ }^{110}$ This is commendable as it allows producers in a member state to source cheaper raw materials from another state without disqualifying the final product from preferential treatment. ${ }^{11}$

Nevertheless, certain provisions on rules of origin remain ambiguous as the rules of origin do not set out the processes that confer origin neither do the rules specify the percentage of originating material required for goods to be considered as sufficiently worked on or processed. This is likely to have adverse effects on trade as member states will have the leeway to adopt varying and high average percentage value requirements for non-originating material. ${ }^{12}$ The percentage of originating material as well as the specific processes that confer origin should be considered during the ongoing negotiations as issues of key importance.

Overlapping membership in various RTAs has been one of the biggest challenges facing regional integration in Africa as it complicates the administration and adds to costs of compliance, both for traders as well as government. Accordingly, the creation of a uniform set of rules of origin addresses the challenge of overlapping, duplex, and complicated rules of origin.

\section{iii. Technical barriers to trade (TBT)}

Technical barriers to trade may exist in the form of: regulations, and standards including packaging, labelling, and marking requirements; conformity assessments; and certificates of free sale. ${ }^{113}$ TBTs are regulated under Annex 6 of the AfCFTA. State parties recognise their rights and obligations under the WTO TBT Agreement in respect of their obligations on technical regulations, and state parties agree that the WTO Agreement on Technical Barriers to Trade form part of the basis of the Annex on TBTs. ${ }^{114}$ Article 5 of the TBT Annex requires state parties to cooperate in the development and implementation of standards, technical regulations, conformity assessment procedures, accreditation, metrology, capacity building and enforcement activities in order to facilitate trade within the

\footnotetext{
Article 14 (2) Annex 2 Rules of Origin, Annexes to the AfCFTA.

111 Qoto L, 'The COMESA-SADC-EAC free trade area: Rules of origin-An impediment to regional trade and economic integration?' Unpublished LLM Thesis, University of Kwazulu Natal, Durban, 2018, 55.

112 Brenton $\mathrm{P} e t \mathrm{al}$, 'Rules of origin and SADC: The case for change in the mid-term review of the Trade Protocol', para 2, 15.

113 Appendix 1, Annex 5 NTBs, Annexes to the AfCFTA.

114 Article 3 Annex 6 TBT, Annexes to the AfCFTA.
} 
AfCFTA. ${ }^{115}$ In the development and implementation of technical regulations, state parties are required to promote the application of good regulatory practices and compliance with the WTO TBT Agreement and international standards on technical regulations. ${ }^{116}$ The AfCFTA requires member states to promote the adoption of standards developed by regional standardisation organisations such as the African Organisation for Standardisation (ARSO) and the African Electrotechnical Standardisation Commission (AFSEC). ${ }^{117}$ The AfCFTA promotes the harmonisation of technical measures by promoting the adoption of standards developed by a single regional standardisation organisation. This addresses the overlapping, duplication and contradiction challenges facing technical measures implemented by different RTAs.

\section{iv. Sanitary and phytosanitary measures}

SPS measures are regulated in Annex 7 of the Annexes to the AfCFTA that seeks to harmonise SPS measures based on international standards and guidelines. Article 3 of Annex 7 of the AfCFTA adopts the provisions of the WTO Agreement on SPS as the guiding principles in the adoption of the application of SPS measures. ${ }^{118}$ The AfCFTA SPS provisions expressly undertake to recognise guidelines of regionalisation and zoning as outlined in the Terrestrial and Aquatic Animal Health Codes of the World Organisation for Animal Health. ${ }^{119}$ This is narrower than the WTO SPS provisions which do not specify which international organisation's criteria will be used. ${ }^{120}$ The WTO SPS simply recognises relevant international organisations. ${ }^{121}$ This is a commendable limitation as it sets out one standard criterion to be used in regionalisation and zoning of plants and animals. Consequently, this eliminates the overlapping and duplication of standardisation guidelines.

In addition, state parties can also request recognition of a special status with respect to a disease not subject to zoning in the codes of the World Organisation for Animal Health. ${ }^{122}$ An importing state party may request additional guarantees for imports of live animals, animal products, and animal by-products appropriate

\footnotetext{
115 Article 5 Annex 6 TBT, Annexes to the AfCFTA.

116 Article 7 Annex 6 TBT, Annexes to the AfCFTA.

117 Article 6 Annex 6 TBT, Annexes to the AfCFTA.

118 Article 3, Annex 7 SPS, Annexes to the AfCFTA.

119 Article 6(a) Annex 7 SPS, Annexes to the AfCFTA.

${ }_{120}$ Article 6 (1), WTO SPS Agreement.

121 Article 6 (1), WTO SPS Agreement.

122 Article 6 (b) Annex 7 SPS, Annexes to the AfCFTA.
}

Vol. 6:1 (2021) p. 186 
to the agreed status recognised by the importing state party, including conditions deemed necessary by the importing state party to achieve an appropriate level of sanitary protection. ${ }^{123}$ This provision is problematic as member states can abuse this provision and implement restrictive SPS measures. This is because the provisions do not define instances that may require recognition as special status circumstances.

Another key feature of the AfCFTA regulation of SPS is the inclusion and recognition of emergency SPS measures. ${ }^{124}$ State parties should give notice of emergency SPS measures within forty-eight-(48) hours of the decision to implement the measure. ${ }^{125} \mathrm{~A}$ state party may request technical consultations to address the emergency SPS measure, and state parties shall consider any information provided through the technical consultations. ${ }^{126}$ It is commendable that the AfCFTA sets a time limit by which an emergency SPS measure must be notified. This will ensure that there are no unnecessary delays in reporting emergency measures. However, the AfCFTA does not define the legal parameters of situations that call for emergency SPS measures and leaves this open for member states to decide. The lack of a set criterion defining the situations that call of emergency may lead to the abuse of emergency SPS measures.

\section{v. Specific limitations}

Specific limitations are control measures that obstruct the quantity of goods that can be imported or exported. ${ }^{127}$ They exist in different forms such tariff quotas, non-automatic licensing, quantitative restrictions, prohibitions and other restrictions with a similar effect. ${ }^{128}$ Though the AfCFTA recognises a wide range of specific limitations, it does not provide clear definitions and regulations on all categories of listed specific limitations.

With regard to the prohibition on quantitative restrictions, Article 9 of the Protocol on the Establishment of Goods prohibits member states from imposing quantitative restrictions on imports or exports to other state parties except as otherwise provided for in the Protocol and Article XI of GATT on the general prohibition on quantitative restrictions or other WTO Agreements.

\footnotetext{
123 Article 6 (b) Annex 7 SPS, Annexes to the AfCFTA.

124 Article 13 Annex 7 SPS, Annexes to the AfCFTA.

125 Article 13 Annex 7 SPS, Annexes to the AfCFTA.

126 Article 13 Annex 7 SPS, Annexes to the AfCFTA.

127 United Nations Conference on Trade and Development, Classification of non-tariff measures, $2012,26$.

128 Appendix 1 Annex 5 NTBs, Annexes to the AfCFTA.
} 
This provision does not add any improvements on the provisions prohibiting the use of quantitative restrictions in RTAs. The AfCFTA simply contains a general prohibition clause that is similar to that found in the legal framework of existing RTAs. The AfCFTA fails to appreciate the fact that the general prohibition on the use of quantitative restriction in RTAs has not reduced their prevalence across the continent and should include provisions that promote political will to eliminate NTBs.

On the other hand, a tariff quota is a quantity which can be imported at a certain duty, and any quantity above that amount is subject to a higher tariff. ${ }^{129}$ For example, a country may allow the importation of 1000 ventilator machines at 5 percent ad valorem and any ventilator machine imported above this quantity will be charged 25 percent ad valorem. Article 6 Annex 4 on Trade Facilitation envisages the use of tariff quotas by countries and requires countries to publish information on whether a good is subject to a tariff quota and procedures relating to the administration of the tariff quotas. Accordingly, it follows from Article 6 of Annex 4 on Trade Facilitation, that the use of tariff quotas is not per se unlawful despite their classification as specific limitations to trade. Though tariff quotas are not traditionally recognised NTBs, their recognition as specific limitations to trade is a commendable inclusion that acknowledges the fact that in some instances tariff quotas may restrict trade where they lead to unreasonably high costs. ${ }^{130}$

\section{vi. Charges on imports}

Charges on imports include: prior import deposits; surcharges, port taxes, statistical taxes; credit restrictions; and Border tax adjustments.

Import charges are prohibited under Article 7 of the Protocol on the Trade in Goods that requires member state to eliminate import charges progressively and refrain from imposing any new import charges that may affect goods originating from the territory of another state party. ${ }^{131}$ While Article 7 of the Protocol on the Trade in Goods prohibits the use of import charges, a reading of Article 21 Annex 4 on Trade Facilitation demonstrates that import charges are permissible so long as import charges are not calculated on an ad valorem

\footnotetext{
129 Bossche P, The law and policy of the World Trade Organisation: Text, cases and materials, 443.

130 Skully W, 'Economics of tariff quota administration' U.S Department of Agriculture: Market and Trade Economics Division, Economic Research Service, Technical Bulletin No. 1893, 2011, 1 - https://www.ers.usda.gov/webdocs/publications/47379/31998_tb1893_002.pdf?v=0 on 21 January 2021.

131 Article 7, AfCFTA Protocol on the Trade in Goods.
}

Vol. 6:1 (2021) p. 188 
basis and do not represent indirect protection to domestic goods or a taxation of imports, exports or goods in transit for fiscal purposes. ${ }^{132}$ Each state party is required to publish a list of fees and charges imposed and shall not apply such fees until information on the charges has been published. There seems to be a contradiction on the use of charges on imports as Article 7 of the Protocol on the Trade in Goods calls for the reduction and elimination of import charges while Article 21 of Annex 4 on Trade Facilitation permits the use of import charges provided that that they do not distort trade and have been published. The AfCFTA is not clear as to whether the application of Article 21 of Annex 4 on Trade Facilitation is limited to existing import charges before their elimination as provided for under Article 7 of the Protocol on the Trade in Goods.

The inclusion of provisions on import charges is commendable as it recognises that import charges may cause barriers to trade. None of the existing RTAs contain provisions on the use of import charges.

\section{vii. Institutions for the Elimination of NTBs in the AfCFTA}

The AfCFTA creates different institutions at the national, REC level and the AfCFTA level that seek to identify, monitor, report and resolve NTBs.

To identify and monitor NTBs, the AfCFTA has established different institutions that are empowered to monitor compliance to commitments towards eliminating NTBs. At the national level, Article 6(2) (a) Annex 5 on Non-Tariff Barriers, requires each state party to establish a National Monitoring Committee and a National Focal Point. ${ }^{133}$ The National Monitoring Committees shall be in charge of identifying, resolving, monitoring and coming up with a process for eliminating NTBs in each state. ${ }^{134}$ On the other hand, the National Focal Points are mandated with coordinating the implementation of the AfCFTA mechanism on the elimination of NTBS by tracking and reporting on the elimination of NTBS to the Secretariat. ${ }^{135}$ At the REC level, the AfCFTA requires RECs to establish or strengthen their NTBs monitoring mechanisms responsible for tracking and monitoring NTBs. ${ }^{136}$ At the AfCFTA level, the AfCFTA establishes a sub-committee of NTBs whose functions shall be to develop an action plan for the implementation of the procedures for the elimination of NTBs

\footnotetext{
Article 21 Annex 4 on Trade Facilitation, Annexes to the AfCFTA.

Article 6 (2) (a) Annex 5 on Non-Tariff Barriers, Annexes to the AfCFTA.

Article 8 (2) Annex 5 on Non-Tariff Barriers, Annexes to the AfCFTA.

Article 9 Annex 5 on Non-Tariff Barriers, Annexes to the AfCFTA.

36 Article 10(1) (a) Annex 5 on Non-Tariff Barriers, Annexes to the AfCFTA.
}

Vol. 6:1 (2021) p. 189 
and monitor the implementation of Annex 5 on Non-Tariff Barriers, ${ }^{137}$ The NTBs Sub-Committee together with the Secretariat shall establish an NTB Coordination unit in-charge of coordinating the working together of the NTB Sub-Committee, National Focal Points and Regional Economic Communities. ${ }^{138}$ These institutions are vital for the implementation and enforcement of NTB commitments under the AfCFTA.

To promote the reporting and resolving of NTBs, Article 12 Annex 5 on Non-Tariff Barriers provides for the establishment of an AfCFTA NTB online mechanism. ${ }^{139}$ The creation of an online reporting mechanism is commendable as the platform will provide a reporting mechanism for member states that are not part of the RTAs and that have already launched reporting mechanisms. ${ }^{140}$ However, unlike the reporting mechanisms launched by RTAs that accept complaints from individuals, standing in the online mechanisms is limited to member states and individuals cannot present disputes to the mechanism. ${ }^{141}$ This may make the online mechanism inefficient as abhorrent trade violations will continue in cases where no government is willing to take up the matter before the online mechanism. ${ }^{142}$

In addition, unlike the online mechanisms launched by RECs, the AfCFTA provides for the use of judicial systems and remedies when parties fail to resolve the disputed NTB. A state party may resort to the dispute settlement stage if they fail to resolve an NTB after a factual report has been issued and a mutually agreed solution has been reached. ${ }^{143}$ Parties may also agree to submit the NTB dispute to arbitration in accordance with the provisions of the Protocol on the Rules and Procedures on the Settlement of Disputes. ${ }^{144}$

\section{Recommendations}

The AfCFTA legal framework on elimination of NTBs is an important element in the elimination of NTBS across Africa. The legal framework must be clear, comprehensive, and coherent for it to be a useful tool in NTB elimination.

\footnotetext{
137 Article 5 (a) and (b) Annex 5 on Non-Tariff Barriers, Annexes to the AfCFTA.

138 Article 6(1) and 7 Annex 5 on Non-Tariff Barriers, Annexes to the AfCFTA.

139 Article 12 Annex 5 on Non-Tariff Barriers, Annexes to the AfCFTA.

140 Article 12 (4) Annex 5 on Non-Tariff Barriers, Annexes to the AfCFTA.

141 Appendix 2 Annex 5 on Non-Tariff Barriers, Annexes to the AfCFTA.

142 Glen T. Schuyle, 'Power to the people: Allowing private parties to raise claims before the WTO dispute resolution system'65(1) Fordham Law Review, 1997, 2277.

143 Section 2.2.3 (d) Appendix 2 Annex 5 on Non-Tariff Barriers, Annexes to the AfCFTA

144 Section 2.2.3 (e) Appendix 2 Annex 5 on Non-Tariff Barriers, Annexes to the AfCFTA.
}

Vol. 6:1 (2021) p. 190 
While the AfCFTA makes some commendable improvements on the regulation of NTBS, some provisions need to be reconsidered to ensure that the legal and institutional framework successfully fills the gaps existing in the regulation of NTBs in RTAs. Below are some amendments that may be made to the AfCFTA.

First, if the AfCFTA is to be successful in eliminating NTBs, it should ensure that its legal framework adequately addresses all the categories of NTBs envisioned in Annex 5 of the AfCFTA Agreement. NTBs such as subsidies, restrictive practices tolerated by governments and import licensing are mentioned as recognised NTBs but are not addressed deeply in other provisions in the AfCFTA. This is likely to lead to challenges in identifying instances where these NTBs arise. This leaves the NTBs unclear and susceptible to broad interpretation and manipulation and can bring about unpredictability in the regulation of NTBs. The AfCFTA should define and set out legal tests that can be used to identify and regulate all the categories of NTBs identified.

To reduce the challenge of overlapping and duplication of health and safety measures and administrative procedures such as custom procedures, the AfCFTA should harmonise different RTA policy frameworks that lead to multiple standards. The continued operation of existing RTAs will undoubtedly delay the harmonisation of rules of origin, SPS and border processes in accordance with the AfCFTA. The AfCFTA should consider setting out mandatory regional standards for use by all member states. Alternatively, the AfCFTA could encourage RTA member states to recognise each other's conformity assessment procedures. This would mean that RTAs would recognise each other's standards or conformity assessment procedures as equivalent to one's own standards even if they are not identical. The harmonization or recognition of each other's standards and procedures will ensure that products moving across different RTAs do not have to go through a myriad of regulations in different RTAs. In addition, to avoid ambiguity on provisions on SPS measures, the AfCFTA should set out legal guidelines on situations that qualify as special status situations where a state party may request additional guarantees. It should also define 'emergency situations' that warrant the use of emergency SPS measures.

To ensure that governments do not implement restrictive trade policies, the AfCFTA should reconsider its provisions on the protection of infant industries and industries of strategic importance. ${ }^{145}$ Article 24 of the Agreement Establishing the AfCFTA should be amended to give a specific definition of infant industries and industries of strategic importance to ensure that there is a

145 Mukucha Ephraim, 'The regulation and impact of non-tariff barriers to trade in SADC free trade area' 42. 
set criterion on the type of industries that are eligible for protection under the Article. In addition, the provision should also be amended to include specific time limits restricting the period when an industry may be protected. This will ensure that governments do not abuse the provision by protecting certain industries for an unreasonable number of years. Alternatively, the AfCFTA could consider abrogating Article 24 in its entirety to avoid the cobra effect that arises from protecting infant industries. ${ }^{146}$

To prevent the implementation of restrictive trade measures and practices such as quantitative restrictions and cumbersome customs procedures tolerated by governments the AfCFTA must go beyond the requirements and commitments to eliminate quantitative restrictions and harmonise customs procedures. The AfCFTA should also include detailed strategies and schedules on the action plan for the elimination of quantitative restrictions and cumbersome customs procedures. For example, the AfCFTA should go beyond the inclusion of regulations simply restricting the use of quantitative restrictions. The AfCFTA should include specific provisions on ways to engage member states on how to limit pre-shipment inspections and other quantitative restrictions that traders face. ${ }^{147}$ This will guarantee that the AfCFTA goes beyond the mere prohibition of quantitative restrictions that exist in the current RTA instruments but have not been observed. These strategies should include detailed provisions on ways that relevant stakeholders will cooperate in working towards elimination of NTBs. To ensure compliance, the AfCFTA should include set timelines by which state parties should have made certain tangible progress and the consequences that arise where member states fail to meet their commitment on elimination of NTBs. ${ }^{148}$

To ensure that rules of origin are not used to limit market access, the AfCFTA should expressly set out a low percentage value threshold for nonoriginating material. This will ensure that producers have a wide range of options from which to source cheap raw materials. ${ }^{149}$ The rules of origin should also set out the specific processes that confer originating status.

146 Protecting infant-industry supresses the capacity of industries to grow into high-yielding and competitive firms and disregards the benefits of comparative advantage as opposed to the intended objective of promoting infant industries. See United States Agency for International Development (USAID), Infant-industry protection and trade liberalization in developing countries, 2004, 31.

147 United Nations Economic Commission for Africa, Regional integration and non-tariff measures in the Economic Community of West African States (ECOWAS), 2018, 32.

148 Mukucha Ephraim, 'The regulation and impact of non-tariff barriers to trade in SADC free trade area' Unpublished LLM Thesis, University of Pretoria, Pretoria, 2011, 50.

149 Brenton P et al, 'Rules of origin and SADC: The Case for change in the mid-term review of the Trade Protocol', 15.

Vol. 6:1 (2021) p. 192 
Finally, to successfully remove NTBs, the legal frameworks put in place must be supported by robust institutions with the power to monitor compliance with obligations about the elimination of NTBs. To ensure that the online NTB reporting mechanism is more effective, traders and businesspersons should be granted standing in the online mechanism. Such a system would be efficient in monitoring and remedying NTB complaints made by traders directly affected by NTBs.

\section{Conclusion}

NTBs remain a serious threat to the liberalisation of trade in Africa and must be addressed by a comprehensive legal framework suitable to addressing challenges faced in eliminating NTBs. This research paper examined the legal and institutional framework on NTBs by analysing the texts of the different RTAs in Africa and the AfCFTA addressing NTBs. The paper identified the different categories of NTBs across the continent and identified NTBs such as: trade distorting subsidies; quantitative restrictions; overlapping and duplicated health and safety measures and technical barriers to trade: and administrative NTBs such as complex rules of origin and cumbersome customs procedures as some of the NTBs most prevalent in Africa.

This article highlighted some of the legal provisions on the NTBs common in Africa and discussed the shortcomings in the different legal frameworks. The paper noted that NTBs are common in Africa due to the overlapping and complex administrative requirements and lack of commitment towards eliminating NTBs despite the general prohibition of NTBs in the AfCFTA. The paper also noted that the lack of proper judicial mechanisms to address NTBs in RTAs undermines the efficiency of the online dispute resolution mechanisms in addressing NTBs that are a result of flawed domestic policy. However, in analysing the institutional framework on eliminating NTBs in the AfCFTA, it was noted that the online mechanisms in the AfCFTA provide for judicial remedies if the parties are unable to reach a mutually agreeable solution. This is an improvement from the NTB online reporting mechanisms established under the RTAs. Nonetheless, the AfCFTA online mechanism does not grant traders directly affected by NTBs a complaint mechanism as only state parties are granted standing.

This research notes that the AfCFTA makes some significant improvements beyond RTAs on regulating NTBs by: categorising and recognising a broad range of NTBs; recognising tariff quotas as specific limitations to trade; adopting less restrictive rules of origin; and appreciating the role of technology in facilitating 
international trade as it includes the call for the use of information technology systems to eliminate the slow customs and border entry requirements. However, this paper also found that despite the recognition of a broad range of NTBs in the AfCFTA legal framework, some legal provisions are weak in addressing the prevalence of NTBs in the region due to the presence of exceptions that allow member states to derogate from their obligation to eliminate NTBs and lack of detailed regulations on the use of allowable NTMs.

It is also noted that while the AfCFTA acknowledges the importance of harmonizing procedures and standards across RECs, the AfCFTA seeks to use RECs as building blocks and provides for the continued operation of the existing RECs. This may lead to delays and challenges in the harmonisation of standards and procedures as different RECs have different standards and procedures.

To this end, it is suggested that the AfCFTA provisions on NTBs should be revisited and reconceptualised to incorporate the suggestions given in this paper. Considering that there are still pending negotiations on the AfCFTA, the drafters of the AfCFTA have a window of opportunity, before the conclusion of all negotiations, to reconsider the provisions on NTBs to ensure they address the problem of 'thick' borders in Africa. 